\title{
DAKWAH BIL QALAM MELALUI INSTAGRAM
}

\author{
Rasmi \\ Institut Agama Islam Negeri Parepare \\ e-mail rasmi005@iainpare.ac.id
}

\begin{abstract}
Abstrak
Penelitian ini bertujuan untuk mengetahui apa itu dakwah Bil Qalam dan mendeskripsikan bagaimana pemanfaatan media sosial Instagram dalam dakwah Bil Qalam. Dakwah tidak harus dengan berdiri di atas mimbar, ada banyak metode yan dapat dilakukan dalam menyampaikan pesan dakwah. Dakwah Bil Qalam merupakan metode dakwah yang menggunakan tulisan dalam menyampaikan sebuah pesan dakwah. Di era digital saat ini, dakwah virtual melalui media sosial Instagram menjadi jalan agar estafet dakwah yang dilakukan Rasulullah SAW tidak terputus begitu saja. Metode dakwah Bil Qalam melalui Instagram dapat berupa caption pada unggahan gambar atau video dan tulisan pada instagram story. Dalam penelitian, peneliti menggunakan pendekatan deskriptif kualitatif. Data penelitiaan kualitatif diinterperetasikan oleh peneliti sehingga hasil penelitian sangat dipengaruhi oleh pemikiran, pandangan, dan pengetahuan peneliti. Data yang dikumpulkan berupa data primer yaitu hasil wawancara dan data sekunder seperti buku, jurnal, dan artikel dakwah yang diperoleh dari internet.
\end{abstract}

Kata kunci: Dakwah Bil Qalam, Media sosial, Instagram.

\begin{abstract}
This study aims to find out what is Da'wah Bil Qalam and describe how to use Instagram social media in Da'wah Bil Qalam. Da'wah does not have to stand on the stand, there are many methods that can be used in conveying the message of da'wah. Da'wah Bil Qalam is a method of da'wah that uses writing in conveying a message of da'wah. In today's digital era, virtual preaching through social media Instagram is a way for the preaching relay conducted by Rasulullah SAW to not be interrupted. The method of preaching Bil Qalam through Instagram can be in the form of a caption on the upload of images or videos and writing on instagram stories. In this study, researchers used a qualitative descriptive approach. The qualitative research data is interpreted by the researcher so that the research results are strongly influenced by the thoughts, views, and knowledge of the researcher. Data collected in the form of primary data are interviews and secondary data such as books, journals and propaganda articles obtained from the internet.
\end{abstract}

Keywords: Da'wah Bil Qalam, Social media, Instagram. 


\section{PENDAHULUAN \\ Latar Belakang}

Dakwah merupakan kegiatan yang berupa ajakan atau seruan kepada manusia untuk melakukan kebaikan dan mengikuti petunjuk. Dakwah telah dilakukan sejak zaman Rasulullah SAW dengan tujuan agar masyarakat Arab meninggalkan kejahiliyahan yang terjadi pada masa itu. Berbagai strategi dakwah yang digunakan Rasulullah SAW, mulai dari dakwah secara sembunyi-sembunyi maupun secara terang-terangan. Selain itu Rasulullah SAW menggunakan berbagai media dalam berdakwah, salah satu media yang digunakan yaitu surat. Dakwah melalui surat biasanya digunakan untuk mengajak para pemimpin besar agar masuk Islam.

Sejak munculnya pandemi Covid-19 di Indonesia pada awal bulan Maret lalu, berbagai upaya telah dilakukan untuk memutus rantai penyebaran virus tersebut. Hal itu menghambat kegiatan dakwah yang biasanya secara tatap muka sebab adanya himbauan untuk menjaga jarak, larangan membuat perkumpulan hingga penutupan tempat-tempat ibadah. Segala aktivitas yang biasa dilakukan setiap hari, kini beralih menggunakan media daring.

Di era digital saat ini, dakwah virtual menjadi jalan agar estafet dakwah yang dilakukan Rasulullah SAW tidak terputus begitu saja. Banyaknya flatform media seharusnya dijadikan sebagai kesempatan bagi para pendakwah untuk semakin kreatif dalam menyampaikan dakwah.Salah satu metode dakwah yang dapat digunakan yaitu dakwah bil qalam. Dakwah bil qalam sebagai metode dalam berdakwah membantu memperbaiki kelemahan dakwah yang hanya dilakukan dengan lisan melalui tulisan (Fitria:2019). Metode ini dapat dimanfaatkan di masa pandemi Covid-19 sebab dapat dilakukan tanpa harus bertatap muka antara da'i dan mad'u.

Instagram sebagai media sosial yang popular dan paling banyak digunakan diseluruh dunia. Berbeda dengan media sosial lainnya yang berfokokus pada kicauan,Instagram lebih berfokus pada foto dan video durasi pendek sehingga dianggap sebagai media sosial yang menarik. Instagram memiliki banyak fitur dan efek camera yang menarik. Melalui Instagram, pengguna bebas berbagi cerita dan pengalaman kepada pengikutnya tanpa dibatasi oleh jarak dan waktu.Selain untuk mencari jati diri maupun berbisnis di media sosial, Instagram juga dapat digunakan sebagai media dalam berdakwah. Banyak da'i yang memanfaatkan akun media sosial Instagramnya untuk berdakwah melihat banyaknya pengguna Instagram serta kemudahan dalam membuat viral sebuah konten. 


\section{Tujuan Penelitian}

Penelitian ini bertujuan untuk mengetahui apa itu dakwah bil qalam dan mendeskripsikan bagaimana pemanfaatan media sosial Instagram dalam dakwah bil qalam.

\section{Metode Penelitian}

Metode dalam penelitian "Dakwah Bil Qalam Melalui Instagram" ini menggunakan pendekatan deskriptif kualitatif. Creswell mendefinisikan penelitian kualitatif sebagai suatu pendekatan atau penelusuran untuk mengeksplorasi dan memahami gelaja sentral (Raco:2010). Data yang diperoleh berupa kata-kata atau teks yang kemudian dianalisis. Dari hasil analisis tersebut, dapat berupa penggambaran atau deskripsi. Data penelitiaan kualitatif diinterperetasikan oleh peneliti sehingga hasil penelitian sangat dipengaruhi oleh pemikiran, pandangan, dan pengetahuan peneliti. Data yang dikumpulkan berupa data primer yaitu hasil wawancara dan data sekunder seperti buku, jurnal, dan artikel dakwah yang diperoleh dari internet.

\section{PEMBAHASAN}

\section{Pengertian Dakwah Bil Qalam}

Kata dakwah memiliki arti yang cukup luas. Definisi dakwah menurut Kamus besar Bahasa Indonesia (KBBI) yaitu 1) penyiaran; propoganda 2) penyiaran agama dan pengembangannya di kalangan masyarakat; seruan untuk memeluk, mempelajari dan mengamalkan ajaran agama ${ }^{1}$. Secara etimologi, dakwah berasal dari bahasa Arab yaitu da'a, yad'u, da'watan, yang berarti mengajak, menyeru menanggil. Sedangkan dakwah secara terminologi menurut Syekh Ali Mahfudz, adalah upaya mendorong manusia untuk berbuat kebaikan dan mengikuti petunjuk dari Allah Swt, menyuruh mereka berbuat kebaikan, dan mencegah mereka dari perbuatan mungkar agar mendapat kebahagiaan di dunia dan akhirat (Rokhayati:2020). Pengertian tersebut sesuai dengan firman Allah Swt dalam Al-Quran surah Ali Imran:104 yang artinya :

“Dan hendaklah diantara kamu ada segolongan orang yang menyeru kepada kebaikan, menyuruh berbuat yang makruf, dan mencegah dari yang mungkar. Dan mereka itulah orang-orang yang beruntung (QS. Ali Imran:104)”.

\section{${ }^{1} \mathrm{KBBI}$}


Pendapat lainnya yaitu menurut Syaikhul Islam Ibnu Taimiyah, yang mendefinisikan dakwah dengan mengajak seseorang beriman kepada Allah dan kepada apa yang dibawakan oleh para Rasulnya dengan cara membenarkan apa yang mereka beritakan dan mengikuti apa yang mereka perintahkan (Pirol:2019). Dari pengertian tersebut dapat dilihat bahwa tujuan dakwah yaitu untuk mengajak dalam berbuat kebaikan demi mewujudkan kebahagiaan dan kesejahteraan hidup di dunia dan akhirat yang diridhoi oleh Allah Swt dan Nabi Muhammad SAW.

Adapun unsur-unsur dakwah menurut Moh. Ali ‘Aziz (Pirol:2018):

1. Da'i (pelaku dakwah)

Dai'i merupakan unsur terpenting dalam dakwah. Da'i atau pelaku dakwah adalah orang yang menyampaikan dakwah kepada khalayak dan menjadi penentu suksesnya usaha dakwah.

2. Maddah (materi dakwah)

Maddah merupakan isi pesan atau materi yang disampaikan oleh da'i kepada mad'u/audiens/penerima dakwah. Materi dakwah berisikan ajaran Islam yang bersumber dari al-Quran dan al-Sunnah.

3. Mad'u (mitra bicara)

Mad'u merupakan objek dakwah. Mad'u memiliki strata dan tingkatan yang berbedabeda. Seorang da'i hendaklah mencari tahu dan memahami karakter dari siapa saja yang akan menjadi mad'u atau mitra bicaranya. Hal ini penting agar pesan yang disampaikan nantinya dapat diterima dengan baik.

4. Thariqah (metode)

Metode merupakan cara atau langkah-langkah yang ditempuh oleh da'i yang ditentukan secara untuk mencapai suatu tujuan. Para da'i hendaknya menggunakan metode dakwah yang tepat dan sesuai dengan kondisi mad'u selaku penerima pesan dakwah. Metode dakwah dapat berupa dakwah bil al-lisan, dakwah bil al-qalam, maupun dakwahbil alhal.

5. Washilah (media dakwah) wasilah adalah alat yang digunakan oleh da'i dalam menyampaikan dakwah mengenai ajaran Islam. Dakwah yang efektif dihasilkan melalui penggunaan media dakwah yang 
tepat. Media dakwah terbagi menjadi lima yaitu lian, tulisan, lukisan/gambar, audio visual dan akhlak.

6. Atsar (efek dakwah)

Atsar atau efek disebut juga feed back dari proses dakwah. Atsar sering kali dilupakan atau tidak banyak menjadi perhatian para da'i, sebab mereka menganggap bahwa setelah dakwah selesai maka selesai pulalah dakwah. Melakukan analisis atsar dakwah sangatlah penting. Dengan melakukan analalis atsar kesalahan strategi dalam mencapai tujuan dakwah dapat diperbaiki di kemudian hari.

Dakwah bil qalam berasal dari bahasa Arab yang jika ditulis sesuai gramatikal maka akan ditulis ad-da'wah bi al-qalam, terdiri dari dua kata yaitu dakwah dan qalam. Secara terminologi, dakwah bil qalam yaitu suatu upaya menyeru manusia dengan cara bijaksana kepada jalan yang benar sesuai dengan perintah Allah Swt melalui seni lisan (Fitria:2019). Tulisan untuk dakwah diperintahkan oleh Allah Swt sebagaimana Firman-Nya dalam al-Quran surah Al-Qalam:1 yang artinya :

"Nun, demi pena dan apa yang mereka tulis" (QS. Al-Qalam:1).

Dakwah bil qalam menurut KH. Aceng Zakaria memiliki suatu kekuatan tersendiri dalam mengajak mad'u, sebab secara tidak langsung mad'u yang membaca karyanya memiliki pemikiran tersendiri dalam menanggapi suatu permasalahan maupun perdebatan dalam menetapkan hukum yang sesuai dengan koridor Allah Swt juga dapat menjadi referensi dalam menciptakan karya yang baru, serta menjadi pegangan dalam memperdebatkan suatu masalah (Poernomo:2018).

\section{Dakwah Bil Qalam melalui Media Sosial Instagram}

Adanya surat ajakan masuk Islam kepada kaisar Persia serta pemimpin-pemimpin besar pada zaman Rasulullah menjadi contoh dakwah melalui tulisan. Dakwah bil qalam merupakan dakwah yang menggunakan pena atau tulisan. Dakwah bil qalam memiliki efisiensi dalam menyampaikan pesan kepada para mad'u atau khalayak luas. Sebelum adanya internet, media dakwah bil qalam berupa buku, majalah, surat kabar, jurnal dan lainnya. Seiring kemajuan teknologi, dakwah bil qalam tidak hanya dilakukan melalui media cetak, melainkan dapat melalui media maya seperti chatting, website, mailing list, jejaring sosial dan sebagainya. 
"Sekarang hampir semua kehidupan manusia dilakukan secara online, nah bagaimana kita bisa menjadi manusia yang bermanfaat untuk sesama ya dengan menggunakan fasilitas online ini. Semoga dengan karya atau tulisan tulisan kita seseorang dapat berubah dan mendapat hidayah," jelas Siska Anggraini selaku kreator poster islami.

Media sosial diartikan sebagai 'medium' di internet yang memungkinkan penggunanya mempresentasikan dirinya maupun berinteraksi, bekerja sama, berbagi, berkomunikasi, dengan pengguna lain, dan membentuk ikatan sosial secara virtual (Sarkawi:2016). Media sosial dapat memperluas cakupan komunikasi tanpa memandang jarak. Selain itu media sosial juga dapat digunakan untuk berjualan atau berbisnis. Seseorang dapat berkomunikasi, membangun identitas, maupun berinteraksi sosial di berbagai jaringan sosial yang ditawarkan oleh jasa penyedia internet dan aplikasi. Masyarakat tinggal memutuskan jaringan mana yang akan digunakan, bahkan dapat memilih lebih dari satu halaman sosial (Meilinda:2018).

Instagram menjadi media sosial yang paling digemari oleh kalangan anak muda. Menurut Dea Hastika, Instagram adalah sebuah aplikasi berbagi foto yang memungkinkan pengguna mengambil foto, mengedit foto, dan membagikannya ke berbagai media sosial lainnya termasuk Instagram itu sendiri (Hastika:2019). Adapun fitur-fitur yang dihadirkan aplikasi yang dikembangkan oleh Kevin Systrom dan Mike Krieger ini sangat beragam seperti live, stories, IGTV, explore, dan lainnya. Hal tersebut memungkin para penggunanya dapat menikmati gambar video, teks media melalui fitur yang ada.

Pemanfaatan Instagram sebagai media dakwah mempermudah penyampaian pesan dakwah kepada mad'u yang lebih banyak. Siapapun dapat berdakwah sebab dapat dilakukan tanpa harus bertatap muka dengan banyak mad'u. Biasanya jika dilakukan secara bertatap muka, seorang da'i cenderung merasa tegang dan gemetar apalagi jika masih pemula. Lain halnya jika dilakukan melalui tulisan. Sebagaimana alasan saudari Siska, "saya bukan penceramah yang bisa hadir di kajian-kajian umum seperti di masjid atau apapun itu, alasan kuatnya sih karena itu tadi 'sampaikanlah walau hanya satu ayat".

Metode dakwah bil qalam melalui Instagram dapat berupa caption pada unggahan gambar atau video dan tulisan pada instagram story. Follower selaku mad'u dapat berkomentar atau memberi pertanyaan melalui kolom komentar atau direct message yang disediakan Instagram terkait kajian yang diposting. Menurut Imas Mutiawati, berdakwah melalui Instagram memiki beberapa kelebihan sebagai berikut: 
1. Tidak terhalang oleh ruang dan waktu;

2. Dakwah menjadi lebih variatif;

3. Jumlah pengguna internet semakin banyak; dan

4. Hemat biaya dan waktu.

Dakwah melalui tulisan akan lebih bermakna jika dibanding dakwah dibicarakan melalui verbal yang sudah terlalu biasa. Melalui fitur Instagram, seorang da'i dapat menggunggah foto atau video moment tertentu lalu diberi caption yang memiliki unsur dakwah. Tampilan penyajian dakwah bil qalam juga dapat gambar atau video pendek yang berisikan tulisan potongan ayat suci Al-Quran dan hadis.

\section{KESIMPULAN}

Berdasarkan pembahasan dalam penelitian, dapat disimpulkan bahwa dakwah tidaklah harus dengan berdiri diatas mimbar, menggunakan metode melalui lisan yang sudah sangat sering dilakukan oleh para da'i lainnya. ada banyak metode yang dapat dilakukan dalam mengajak atau menyeru pada kebenaran. Dakwah bil qalam merupakan metode dakwah yang menggunakan tulisan dalam menyampaikan sebuah pesan dakwah. Metode ini sangat sangat baik diterapkan selama pandemi Covid-19 di Indonesia sebab dapat dilakukan tanpa harus bertatap muka antara da'i dan mad'u.

Instagram sebagai salah salah satu media sosial yang populer dengan fitur-fitur dan kelebihan memungkinkan para penda'i untuk melakukan dakwah bil qalam. Aplikasi yang berfokus pada gambar dan video ini memiliki daya tarik tersendiri dalam menarik minat penggunanya. Dakwah bil qalam melalui Isntagram dapat dilakukan dengan memberi caption dengan unsur dakwah pada postingan. Selain itu juga dapat dilkukan memposting gambar atau video yang berisakan tulisan-tulisan yang mengandung pesan dakwah. .

\section{DAFTAR PUSTAKA}

Raco, J.R. 2010. Metode Penelitian Kualitatif: Jenis, Karakterisrik dan Keunggulannya.

Gramedia Widiasarana Indonesia: Jakarta.

Rokhayati, Dewi. 2020. Berhijrah Melalui Dakwah Islamiyah Menjadikan Indahnya Islam, dalam http://iqt.unida.gontor.ac.id

Pirol, Abdul. 2018. Komunikasi dan Dakwah Islam. Cetakan Pertama. Deepublish: Yogyakarta. 
Fitria, Rini dan Rafinita Aditia. 2019. Prospek dan Tantangan Dakwah Bil Qalam Sebagai Metode Komunikasi Dakwah. Jurnal Ilmiah Syiar. Vol.19, No.2, 224-234. https://ejournal.iainbengulu.ac.id/index.php/syiar

Poernomo, Imanuel Ihsan Haris. Irfan Safrudin dan Hendin Suhendi. 2018. Analisis Konten Dakwah Bil Qalam KH. Aceng Zakaria (Hidayah Fil Masail Fiqhiyŷah Muta'aridhah). Prosiding Komunikasi Penyiaran Islam. Vol.1, No.1.

Sarkawi, Dahlia. 2016. Perubahan Sosial dan Budaya Akibat Media Sosial. Jurnal Administrasi Kantor. Vol.4 No.2, 307-338, http://ejournalbinainsani.ac.id/index.php/JAKBI/article/view/183/283

Meilinda, Nurly. 2018. Social Media on Campus: Studi Peran Media Sosial Komunikasi FISIP UNSRI. The Journal of Society \&Media. Vol.2(1), 53-64, https://journal.unesa.ac.id/index.php/jsm/index

Hastika, Dhea. 2019. Pengaruh Intensitas Mengakses Instagram Korean Pop Terhadap Perilaku Fanatisme Pada Mahasiswa Dirasat Islamiyah UIN Jakarta. Skripsi. Fakultas Ilmu Dakwah dan Ilmu Komunikasi. Univ. Islam Negeri Syarif Hidayatullah. Jakarta.

Mutiawati, Imas. 2018. Dakwah di Media Sosial: Studi Fenomenologi Dakwah di Instagram. Skripsi. Fakultas Dakwah dan Komunikasi. Univ. Islam Negeri Walisongo. Semarang. 